\title{
Effect of Ga-Addition on the Glass-Forming Ability and Superconducting Properties of $\mathrm{Bi}-\mathrm{Sr}-\mathrm{Ca}-\mathrm{Cu}-\mathrm{O}$ System
}

\author{
Jabri KHALED, Ryuji SATO* and Takayuki KOMATSU \\ Department of Chemistry, Nagaoka University of Technology, 1603-1, Kamitomioka-cho, Nagaoka-shi 940-21 \\ *Department of Material Engineering, Tsuruoka National College of Technology, 104, Sawada, Ioka, Tsuruoka-shi 997 \\ $\mathrm{Bi}-\mathrm{Sr}-\mathrm{Ca}-\mathrm{Cu}-\mathrm{O}$ 系のガラス形成能及び超伝導特性に対する $\mathrm{Ga}$ 添加効果 \\ Jabri Khaled ·佐藤隆士* · 小松高行 \\ 長岡技術科学大学化学系, 940-21 新潟県長岡市上富岡町 1603-1 \\ *鶴岡工業高等専門学校物質工学科, 997 山形県鶴岡市大字井岡字沢田 104
}

\begin{abstract}
The effect of the addition of $\mathrm{Ga}_{2} \mathrm{O}_{3}$, a conditional glass former, on the glass-forming ability and superconducting properties of samples with $\mathrm{Bi}_{2-x} \mathrm{Ga}_{x} \mathrm{Sr}_{2} \mathrm{Ca}_{2} \mathrm{Cu}_{3} \mathrm{O}_{y}(x=0-1.5)$ compositions has been investigated. The quantity $T_{x}-T_{g}$ increases from 54 to $68 \mathrm{~K}$, indicating an improvement in the glass forming ability of the samples, where $T_{\mathrm{g}}$ and $T_{\mathrm{x}}$ are glass transition and crystallization temperatures, respectively. The superconducting properties deteriorate due to the migration of $\mathrm{Ga}$ ions into the 2212 phase: the superconducting critical temperature of the 2212 phase decreases from $85 \mathrm{~K}$ for Ga-free sample to $72 \mathrm{~K}$ for the sample with $x=0.5$, and the sample with $x=1.5$ shows semiconducting properties. The $c$-axis length of the 2212 phase decreases from $3.081 \mathrm{~nm}$ for $\mathrm{Ga}$-free sample to $3.074 \mathrm{~nm}$ for the sample with $x=0.5$, but $a$-and $b$-axis lengths remain constant. A new Ga-compound formed in Ga-added samples was identified to be $\mathrm{GaSr}_{0.55} \mathrm{Ca}_{1.05} \mathrm{Cu}_{0.5} \mathrm{O}_{x}$. Superconducting phases of the Ga-based system are not formed even in Ga-rich samples.
\end{abstract}

[Received August 30, 1996; Accepted December 11, 1996]

Key-words : Glass-forming ability, Glass-ceramic superconductors, Bi-Sr-Ca-Cu-O system, $\mathrm{Ga}-\mathrm{Sr}-\mathrm{Ca}-\mathrm{Cu}-\mathrm{O}$ system

1. Introduction

Since the discovery of superconductivity at $120 \mathrm{~K}$ in Bi$\mathrm{Sr}-\mathrm{Ca}-\mathrm{Cu}-\mathrm{O}$ system (Bi-based system), 1) many studies have been carried out on it. Three superconducting phases, $\mathrm{Bi}_{2} \mathrm{Sr}_{2} \mathrm{CuO}_{x}$ (2201 phase), $\mathrm{Bi}_{2} \mathrm{Sr}_{2} \mathrm{CaCu}_{2} \mathrm{O}_{x}$ (2212 phase) and $\mathrm{Bi}_{2} \mathrm{Sr}_{2} \mathrm{Ca}_{2} \mathrm{Cu}_{3} \mathrm{O}_{x}$ (2223 phase) have been observed. The two last phases show superconductivity at critical temperatures, $T_{c}$, as high as 85 and $110 \mathrm{~K}$, respectively, that make them of much interest. Their high- $T_{\mathrm{c}}$ alone is not an enough condition for their use in practice. Other superconducting properties such as critical electric current density are far below the application values required and this in itself represents a major barrier for using superconductors at large scale. Preparation of superconductors in different shapes is also looked for. One method to shape superconductors in desired forms is to pass through the glass-ceramic route. It is well known that glassy samples with composition corresponding to the 2212 phase are easily prepared by a conventional quenching method. 2),3) However, the 2223 phase could not be transformed into a perfect amorphous state and $\mathrm{CaO}$ was found to precipitate. ${ }^{4)}$

On the other hand, Muromachi and Isobe ${ }^{5)}$ reported the presence of superconductivity in $\mathrm{Ga}-\mathrm{Sr}-\mathrm{Ca}-\mathrm{Cu}-\mathrm{O}$ system (Ga-based system) under higher pressure using the sintering method. However, there is no report on superconductivity in this system under atmospheric pressure. Murugesan et al. $^{6)}$ succeeded in stabilizing the high pressure superconducting $\mathrm{TbSr}_{2} \mathrm{Cu}_{2.85} \mathrm{Re}_{0.15} \mathrm{O}_{x}$ ( $\mathrm{Tb}$-based system) by adding Re. Hahakura ${ }^{7}$ in their turn succeeded in stabilizing the high pressure superconducting $(\mathrm{Hg}, \mathrm{Mo}) \mathrm{Sr}_{2} \mathrm{CaCu}_{2} \mathrm{O}_{x}$ by substituting $\mathrm{Y}$ for $30 \%$ of $\mathrm{Ca}$, an indication that the substitution of one or more elements of the high pressure superconducting phase by certain specific elements may be effective in stabilizing the phase at atmospheric pressure.

In the present study, the effect of the substitution of $\mathrm{Ga}_{2} \mathrm{O}_{3}$ on the glass-forming ability and on superconducting properties of $\mathrm{Bi}$-based superconducting glass-ceramics is studied. It is well known that $\mathrm{Ga}_{2} \mathrm{O}_{3}$ is a conditional glass former and the glass formation in the systems of $\mathrm{Bi}_{2} \mathrm{O}_{3}-$ $\mathrm{Ga}_{2} \mathrm{O}_{3}-\mathrm{PbO}$ or $\mathrm{CaO}-\mathrm{Ga}_{2} \mathrm{O}_{3}{ }^{8), 9)}$ has been reported. Further, the possibility of superconductivity in Ga-based system, $\mathrm{GaSr}_{2} \mathrm{CaCu}_{2} \mathrm{O}_{x}$ (1212 phase), $\mathrm{GaSr}_{2} \mathrm{Ca}_{2} \mathrm{Cu}_{3} \mathrm{O}_{x}$ (1223 phase) and $\mathrm{GaSr}_{2} \mathrm{Ca}_{3} \mathrm{Cu}_{4} \mathrm{O}_{x}$ (1234 phase) are also examined.

\section{Experimental}

Samples with nominal compositions $\mathrm{Bi}_{2-x} \mathrm{Ga}_{x} \mathrm{Sr}_{2} \mathrm{Ca}_{2}$ $\mathrm{Cu}_{3} \mathrm{O}_{2 y}(x=0-1.5)$ were prepared from starting materials of $\mathrm{Bi}_{2} \mathrm{O}_{3}, \mathrm{Ga}_{2} \mathrm{O}_{3}, \mathrm{SrCO}_{3}, \mathrm{CaCO}_{3}$ and $\mathrm{CuO}$. Batches of $10 \mathrm{~g}$ were mixed with methanol and let dry in air until no methanol supposed to remain. The batches were then calcined at $820^{\circ} \mathrm{C}$ for $10 \mathrm{~h}$ in air. Then, they were ground and melted in a platinum crucible at $1300^{\circ} \mathrm{C}$ for $10 \mathrm{~min}$. An intermediate mixing with a silica rod was performed in order to obtain a homogeneous melt. The melts were then poured on an iron plate and pressed quickly with another one. Dark and black samples having a thickness in the order of $1 \mathrm{~mm}$ were obtained. These samples were mounted on alumina boats and underwent a process of annealing for various periods of time at various temperatures. The phases present in the samples were identified by powder X-ray diffraction method with $\mathrm{Cu} \mathrm{K} \alpha$ radiation. Thermal behaviors were monitored by thermal gravimetry and differential thermal analysis, TG/DTA . Electrical resistivities were measured by four-probe technique with an intensity of electric current of $5 \mathrm{~mA}$. AC complex susceptibilities, $\chi=\chi^{\prime}+i \chi$ ", were measured by using a Hartshorn bridge. In all susceptibility measurements, the amplitude of ac field is $0.260 \mathrm{e}$ and the frequency is $713 \mathrm{~Hz}$.

\section{Results and discussion}

3.1 Glass formation and thermal stability

Figure 1 shows XRD powder patterns for as-quenched samples of $\mathrm{Bi}_{2-x} \mathrm{Ga}_{x} \mathrm{Sr}_{2} \mathrm{Ca}_{2} \mathrm{Cu}_{3} \mathrm{O}_{y}$. In $\mathrm{Ga}$-free sample, the peaks attributable to $\mathrm{CaO}$ are observed together with a halo characteristic of amorphous state. In the samples with $x=0.3$ and 0.5 , a slight decrease in the intensity for the 


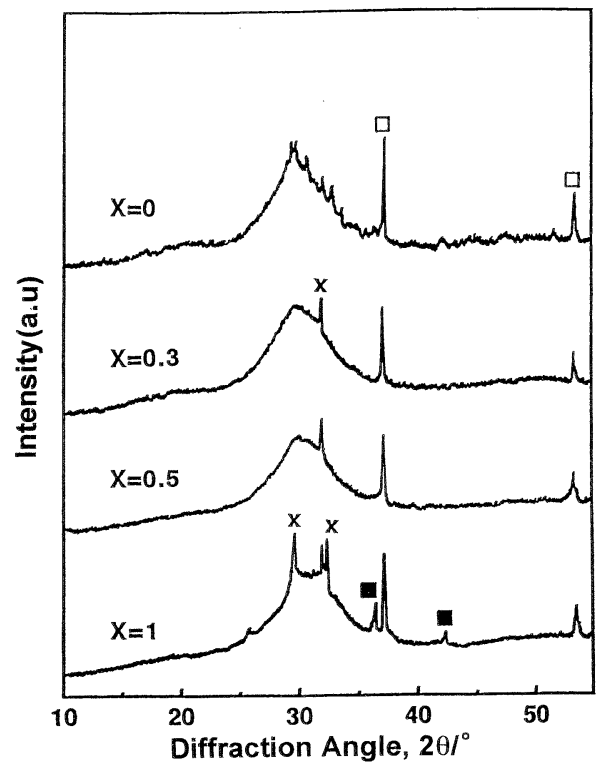

Fig. 1. XRD powder pattern for as-quenched $\mathrm{Bi}_{2-x} \mathrm{Ga}_{x} \mathrm{Sr}_{2} \mathrm{Ca}_{2}$ $\mathrm{Cu}_{3} \mathrm{O}_{y}$ samples.

$\square \mathrm{CaO}, \square \mathrm{Cu}_{2} \mathrm{O}, \times$ unknown.

peaks of $\mathrm{CaO}$ is observed. Further addition of $\mathrm{Ga}_{2} \mathrm{O}_{3}$, however, causes the precipitation of unknown crystalline phases as seen clearly in the XRD pattern for the sample with $x=1$. We notice that in Ga-rich samples, $\mathrm{Cu}_{2} \mathrm{O}$ precipitates. Figure 2 shows the DTA curves for as-quenched bulk samples. The glass transition temperature, $T_{\mathrm{g}}$, of Ga-free sample is $406^{\circ} \mathrm{C}$. The increase in Ga-content increases $T_{g}$ continuously to $421^{\circ} \mathrm{C}$ for the sample with $x=0.5$. The crystallization temperature, $T_{x}$, also increases with increasing $\mathrm{Ga}$-content and goes from $460^{\circ} \mathrm{C}$ for $\mathrm{Ga}$-free sample to $489^{\circ} \mathrm{C}$ for the sample with $x=0.5$. In Ga-rich samples with $x>0.5$, a second exothermic peak due to a second crystallization process is observed at $545^{\circ} \mathrm{C}$. The melting temperature, however, decreases with increasing $\mathrm{Ga}$-content and goes from $898^{\circ} \mathrm{C}$ for Ga-free sample to $869^{\circ} \mathrm{C}$ for the sample with $x=0.5$.

Figure 3 shows XRD powder patterns for samples with various $\mathrm{Ga}$ contents annealed at $840^{\circ} \mathrm{C}$ for $24 \mathrm{~h}$ in air. In Gafree sample, the 2212 phase is the main phase present with

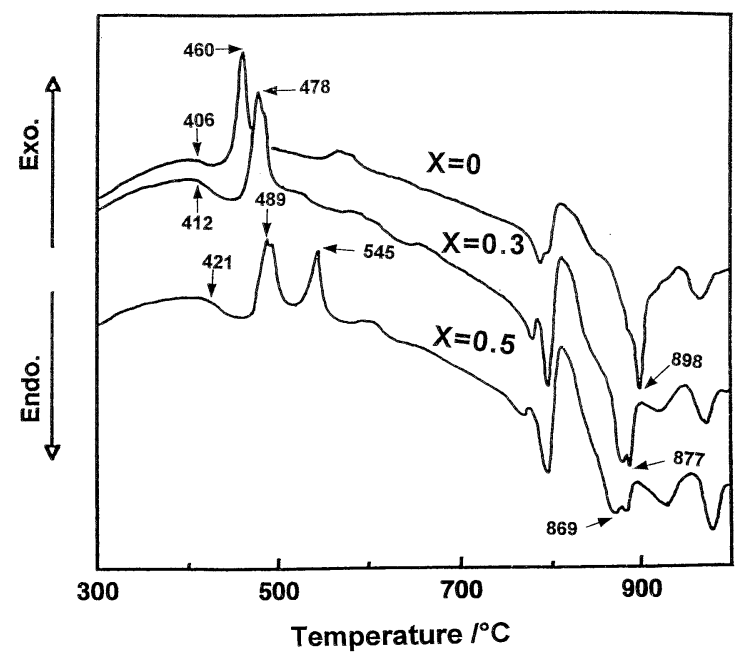

Fig. 2. DTA curves for as quenched bulk samples of $\mathrm{Bi}_{2-x} \mathrm{Ga}_{x} \mathrm{Sr}_{2}$ $\mathrm{Ca}_{2} \mathrm{Cu}_{3} \mathrm{O}_{y}$.

Heating rate is $10 \mathrm{~K} / \mathrm{min}$.

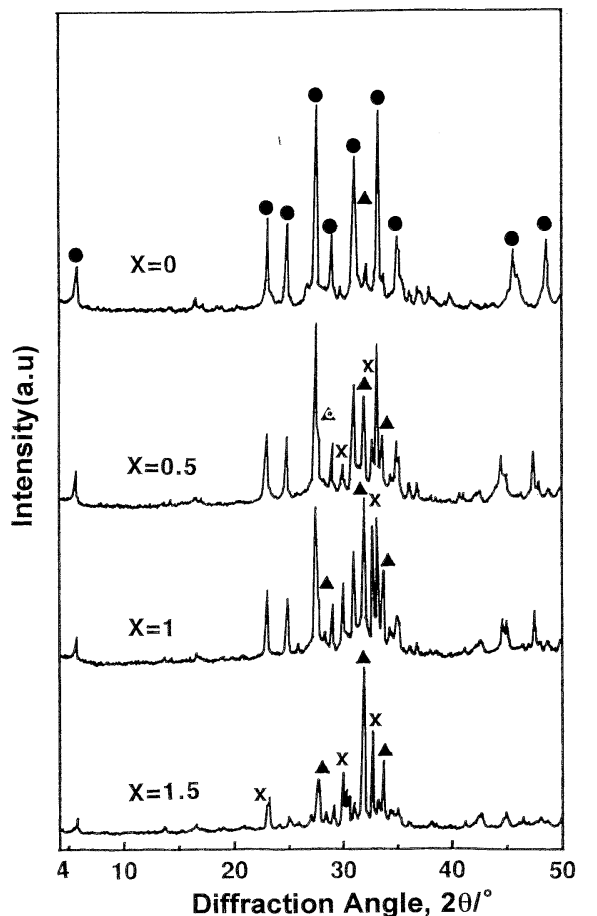

Fig. 3. XRD powder patterns for $\mathrm{Bi}_{2-x} \mathrm{Ga}_{x} \mathrm{Sr}_{2} \mathrm{Ca}_{2} \mathrm{Cu}_{3} \mathrm{O}_{y}$ samples annealed at $840^{\circ} \mathrm{C}$ for $24 \mathrm{~h}$ in air

2212 phase, $\boldsymbol{\Delta} \mathrm{Sr}_{1.5} \mathrm{Ca}_{1.5} \mathrm{Cu}_{5} \mathrm{O}_{x}, \times$ unknown phase.

traces of $\mathrm{Sr}_{1.5} \mathrm{Ca}_{1.5} \mathrm{Cu}_{5} \mathrm{O}_{x}$ compound. ${ }^{10)}$ In Ga-containing samples, along the 2212 phase and $\mathrm{Sr}_{1.5} \mathrm{Ca}_{1.5} \mathrm{Cu}_{5} \mathrm{O}_{x}$, an other unknown phase different from that observed in Fig. 1 and believed to be a Ga-compound is formed, because its peak intensities increase with increasing $\mathrm{Ga}$ content. We point out also the formation of the 2212 phase even in $\mathrm{Bi}$-poor samples of $\mathrm{Bi}_{0.5} \mathrm{Ga}_{1.5} \mathrm{Sr}_{2} \mathrm{Ca}_{2} \mathrm{Cu}_{3} \mathrm{O}_{x}$.

The decrease in the peak intensity of $\mathrm{CaO}$ and the disappearance of several unknown peaks in samples containing up to $x=0.5$ of $\mathrm{GaO}_{3 / 2}$ indicate that the presence of small amount of $\mathrm{Ga}_{2} \mathrm{O}_{3}$ improves the glass forming ability in $\mathrm{Bi}_{2-x}$ $\mathrm{Ga}_{x} \mathrm{Sr}_{2} \mathrm{Ca}_{2} \mathrm{Cu}_{3} \mathrm{O}_{y}$. However, a large substitution of $\mathrm{Ga}_{2} \mathrm{O}_{3}$ for $\mathrm{Bi}_{2} \mathrm{O}_{3}$ has no effect on the glass formation. It has been considered that $\mathrm{Bi}_{2} \mathrm{O}_{3}$ is glass-former in the system of $\left.\mathrm{Bi}-\mathrm{Sr}-\mathrm{Ca}-\mathrm{Cu}-\mathrm{O},{ }^{2)}, 11\right)$ and recently, a glass network structure model of $\left[\mathrm{BiO}_{6}\right]-\mathrm{Cu}^{+}-\left[\mathrm{BiO}_{6}\right]$ has been proposed. ${ }^{12)}$ The present results indicate clearly that $\mathrm{Bi}_{2} \mathrm{O}_{3}$ is more effective for the glass formation compared with $\mathrm{Ga}_{2} \mathrm{O}_{3}$. The precipitation of $\mathrm{Cu}_{2} \mathrm{O}$ in Ga-rich samples might demonstrate the collapse of a network structure of $\left[\mathrm{BiO}_{6}\right]-\mathrm{Cu}^{+}-\left[\mathrm{BiO}_{6}\right]$. In other words, in a small substitution of $\mathrm{Ga}_{2} \mathrm{O}_{3}$ for $\mathrm{Bi}_{2} \mathrm{O}_{3}$, $\mathrm{Ga}^{3+}$ ions might be possible to enter $\mathrm{Bi}^{3+}$ sites, i.e., $\left[\mathrm{BiO}_{6}\right]-$ $\mathrm{Cu}^{+}-\left[\mathrm{GaO}_{6}\right]$, but the formation of $\left[\mathrm{GaO}_{6}\right]-\mathrm{Cu}^{+}-\left[\mathrm{GaO}_{6}\right]$ as a network structure would be ruled out. It should be pointed out that the addition (not substitution) of $\mathrm{Ga}_{2} \mathrm{O}_{3}$ for $\mathrm{Bi}$ based system, e.g., $\mathrm{BiSrCaCu}_{2} \mathrm{Ga}_{x} \mathrm{O}_{y}$, is very effective for the glass formation. ${ }^{13)}$

The increase in $T_{\mathrm{g}}$ and $T_{x}$ with increasing Ga-content is in agreement with that reported by Demesso et al. ${ }^{13)}$ on the $\mathrm{Bi}_{2} \mathrm{Ga}_{x} \mathrm{Sr}_{2} \mathrm{CaCu}_{2} \mathrm{O}_{y}$. The quantity of $T_{x}-T_{\mathrm{g}}$ representing the thermal stability of the glass state increased relatively from 54 to $68 \mathrm{~K}$ for Ga-free sample and $x=0.5$ containing sample, respectively. This increase in $T_{x}-T_{\mathrm{g}}$ shows that the presence of $\mathrm{GaO}_{3 / 2}$ stabilizes the glass state in Bi-based system.

3.2 Superconducting properties

The temperature dependences of the electric resistivities for $\mathrm{Bi}_{2-x} \mathrm{Ga}_{x} \mathrm{Sr}_{2} \mathrm{Ca}_{2} \mathrm{Cu}_{3} \mathrm{O}_{y}$ samples are shown in Fig. 4. In 
samples with $x=0$ (Ga-free), $0.3,0.5$ and 1 (not shown), a zero resistivity is obtained at 50 to $70 \mathrm{~K}$, indicating that the samples containing up to $x=1$ of $\mathrm{GaO}_{3 / 2}$ are superconducting. In sample with $x=1.5$, the zero resistivity is not obtained due to the small fraction of the 2212 phase as shown in Fig. 3. As seen in Fig. 4, the critical temperature (here onset temperature is considered) of the 2212 phase decreases from $85 \mathrm{~K}$ for Ga-free sample to around $72 \mathrm{~K}$ for the sample with $x=0.5$. This decrease is believed to be due to the migration of $\mathrm{Ga}$ ions into the 2212 phase. To clarify this model, the change in lattice parameters of the 2212 phase with Ga content is measured, and the results are shown in Fig. 5. The increase in Ga-content does not affect the $a$ - and $b$-axes lengths. However, it caused a decrease in $c$-axis length which is shortened from $3.081 \mathrm{~nm}$ for Ga-free sample to $3.074 \mathrm{~nm}$ for the sample with $x=0.5$. This decrease in $c$-axis length would suggest the possibility of the migration of $\mathrm{Ga}^{3+}$ into the 2212 phase. Kannan et al. ${ }^{14)}$ examined superconducting properties of $\mathrm{Ga}_{2} \mathrm{O}_{3}$ substituted $\mathrm{Bi} 2212$ system and proposed that the substitution of $\mathrm{Ga}$ is most likely to take place in $\mathrm{BiO}$ bilayers. Since the $\mathrm{Ga}^{3+}$ has an ionic radius of $0.062 \mathrm{~nm}$ close to that $(0.069 \mathrm{~nm})$ of $\mathrm{Cu}^{2+}$, we can not exclude the possibility of the substitution of

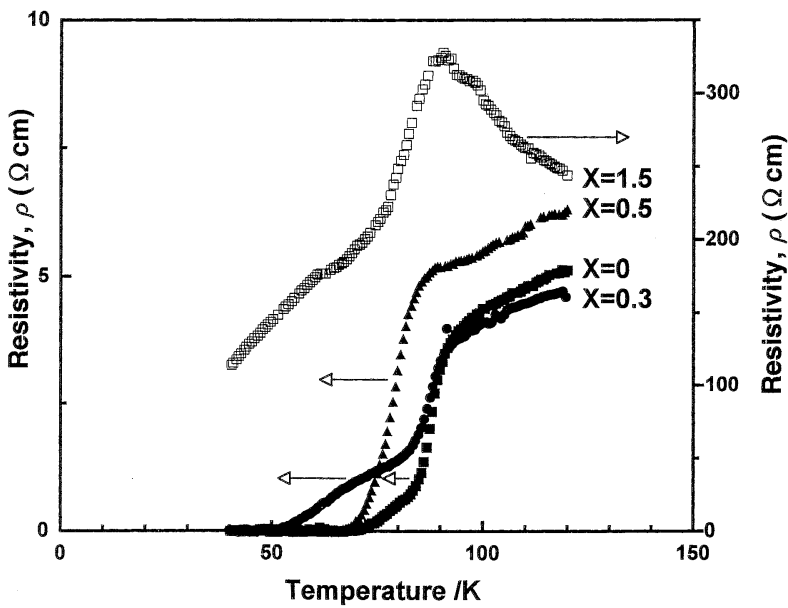

Fig. 4. Temperature dependence of electrical resistivity for $\mathrm{Bi}_{2-x}$ $\mathrm{Ga}_{x} \mathrm{Sr}_{2} \mathrm{Ca}_{2} \mathrm{Cu}_{3} \mathrm{O}_{y}$ samples annealed at $840^{\circ} \mathrm{C}$ for $24 \mathrm{~h}$ in air.

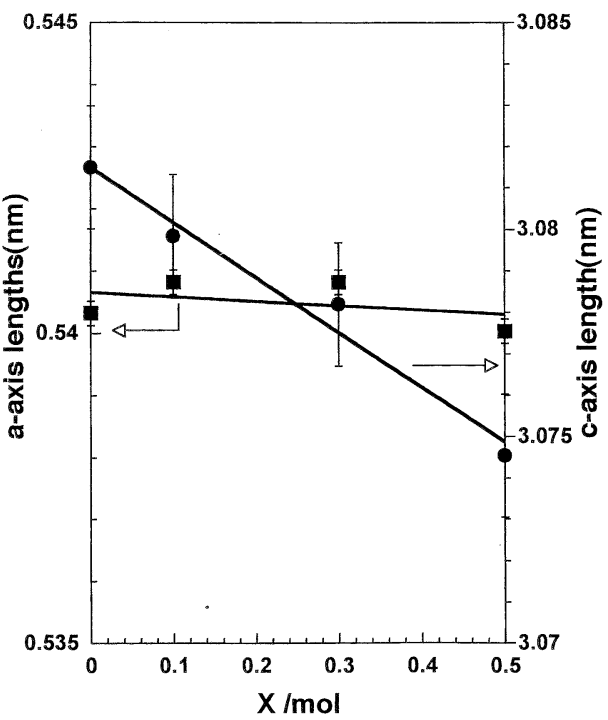

Fig. 5. Lattice parameters for the 2212 phase in $\mathrm{Bi}_{2-x} \mathrm{Ga}_{x} \mathrm{Sr}_{2} \mathrm{Ca}_{2}$ $\mathrm{Cu}_{3} \mathrm{O}_{y}$ samples annealed at $840^{\circ} \mathrm{C}$ for $24 \mathrm{~h}$ in air.

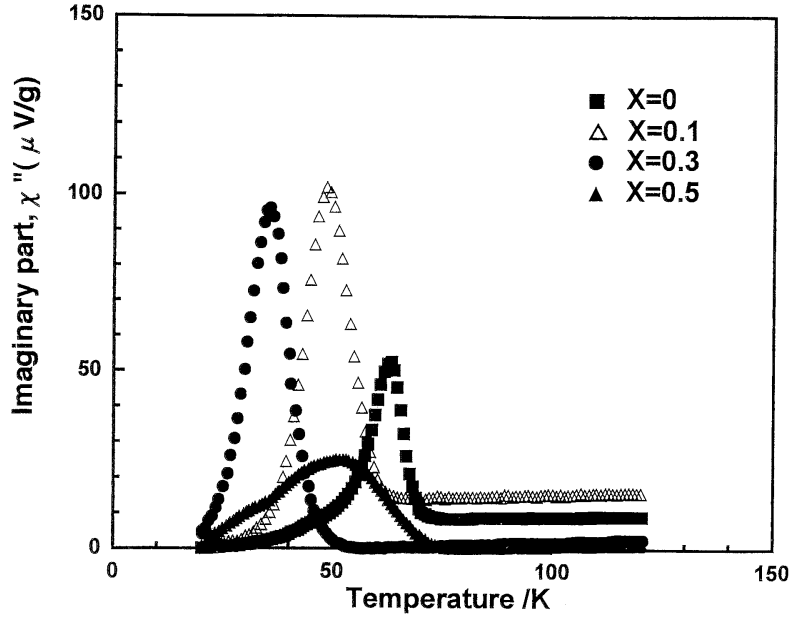

Fig. 6. Temperature dependence of the ac complex susceptibility for $\mathrm{Bi}_{2-x} \mathrm{Ga}_{x} \mathrm{Sr}_{2} \mathrm{Ca}_{2} \mathrm{Cu}_{3} \mathrm{O}_{y}$ samples annealed at $840^{\circ} \mathrm{C}$ for $24 \mathrm{~h}$ in air.

$\mathrm{Ga}^{3+}$ for $\mathrm{Cu}^{2+}$ sites. Regarding the closeness of the radii of $\mathrm{Ga}^{3+}$ and $\mathrm{Cu}^{2+}$, the substitution of $\mathrm{Ga}^{3+}$ into $\mathrm{Cu}^{2+}$ sites will not cause a significant change in the lattice parameters of the 2212 phase. The decrease in lattice parameter is explained by the diffusion of oxygen into the 2212 phase, because $\mathrm{Ga}^{3+}$ has higher electric charge than $\mathrm{Cu}^{2+}$. That is, to keep the neutrality of the system, the diffusion of $\mathrm{Ga}^{3+}$ should be accompanied by a diffusion of oxygen anions. These anions of oxygen will occupy vacant sites in the system and will play a significant role in reducing the repulsive forces between cations, leading to a significant decrease in the lattice parameters.

The presence of $\mathrm{Ga}$ in extra amount is expected to affect the linkage at grain boundaries. The imaginary part of the ac complex susceptibility is a tool to measure the loss at grain boundaries. The temperature dependence of the imaginary part of the complex susceptibility is shown in Fig. 6. In samples containing $\mathrm{Ga}$, the peak due to the transition to superconducting state shifts to lower temperatures, indicating the diffusion of $\mathrm{Ga}$ into the 2212 phase. Also, the peaks become broader with increasing $\mathrm{Ga}$ content, meaning a weakening of the linkage at grain boundaries due to the presence of $\mathrm{Ga}$. The shift in peak position is continuous for samples with $x \leqq 0.3$. For samples with $x=0.5$, the peak is at higher temperature than those for samples with $x \leqq 0.3$. However, it tends to separate into two peaks, one at higher temperature may be mainly due to the transition to superconducting state and the other one to the linkage at grain boundaries. One of the main origin of grain linkage weakening is $\mathrm{Ga}$ residual.

Since Ga-addition affects the superconducting properties of the 2212 phase, it may also affect those of the 2223 phase, because both phases have a similar crystalline structure. Recently, we found that the substitution of $\mathrm{Te}$ for $\mathrm{Cu}$ in $\mathrm{Bi}_{1.6} \mathrm{~Pb}_{0.4} \mathrm{Sr}_{2} \mathrm{Ca}_{2} \mathrm{Cu}_{3-x} \mathrm{Te}_{x} \mathrm{O}_{y}$ enhances significantly the formation kinetics of the 2223 phase. ${ }^{15)}$ Figure 7 shows XRD powder patterns for $\mathrm{Bi}_{1.6-x} \mathrm{Ga}_{x} \mathrm{~Pb}_{0.4} \mathrm{Sr}_{2} \mathrm{Ca}_{2} \mathrm{Cu}_{2.9} \mathrm{Te}_{0.1} \mathrm{O}_{y}$ $(x=0.1$ and 0.3$)$ obtained by annealing at $850^{\circ} \mathrm{C}$ for $48 \mathrm{~h}$ in air. It is seen that the 2223 phase is detected with traces in the sample with $x=0.1$ and completely disappeared in the sample with $x=0.3$. These results indicate that the presence of Ga reduces the kinetics formation of the 2223 phase, unfortunately.

3.3 Formation of Ga-compound

The chemical composition of the unknown Ga-compound has been determined using the sintering method. Giving the lower stability of $\mathrm{Ga}^{3+}$ in five-coordination number environ- 


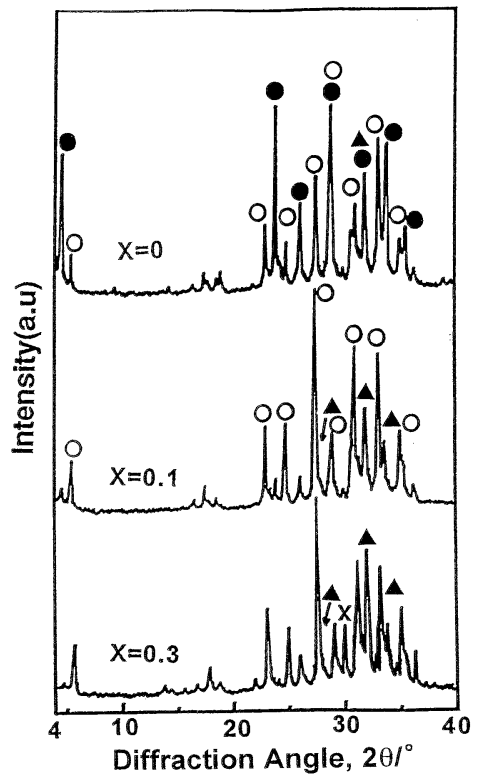

Fig. 7. XRD powder patterns for $\mathrm{Bi}_{1.6-x} \mathrm{Ga}_{x} \mathrm{~Pb}_{0.4} \mathrm{Sr}_{2} \mathrm{Ca}_{2} \mathrm{Cu}_{2.9}$ $\mathrm{Te}_{0,1} \mathrm{O}_{x}$ samples annealed at $850^{\circ} \mathrm{C}$ for $48 \mathrm{~h}$ in air.

2212 phase, 2223 phase, $\boldsymbol{\Delta} \mathrm{Sr}_{1.5} \mathrm{Ca}_{1.5} \mathrm{Cu}_{5} \mathrm{O}_{x}, \times$ unknown phase.

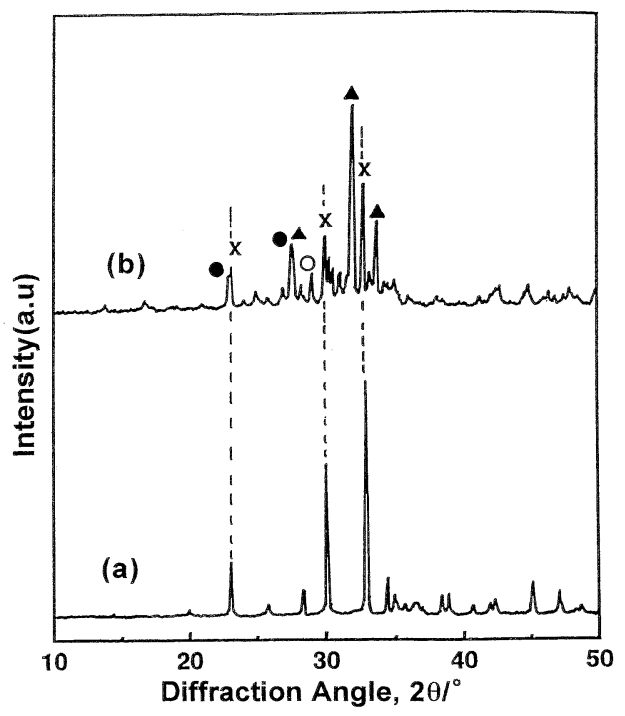

Fig. 8. XRD powder pattern for newly synthesized $\mathrm{GaSr}_{0.55} \mathrm{Ca}_{1.05}$ $\mathrm{Cu}_{0.5} \mathrm{O}_{x}$ compound (a). The pattern for $\mathrm{Bi}_{0.5} \mathrm{Ga}_{1.5} \mathrm{Sr}_{2} \mathrm{Ca}_{2} \mathrm{Cu}_{3} \mathrm{O}_{y}$ sample annealed at $840^{\circ} \mathrm{C}$ for $24 \mathrm{~h}$ is also shown in (b).

ment, $\mathrm{Ga}^{3+}$ are supposed to substitute limited quantity of $\mathrm{Cu}^{2+}$ ions. Figure 8 shows an XRD powder pattern for a newly synthesized Ga-compound, $\mathrm{GaSr}_{0.55} \mathrm{Ca}_{1.05} \mathrm{Cu}_{0.5} \mathrm{O}_{x}$. The XRD pattern for the sample with $x=1.5$ of $\mathrm{GaO}_{3 / 2}$ is shown in Fig. 8, and it is clear that the peaks due to the Ga- compound are strong enough to be easily identified. Based on the positions and intensities of the unidentified peaks, these peaks match well those of the newly synthesized $\mathrm{GaSr}_{0.55} \mathrm{Ca}_{1.05} \mathrm{Cu}_{0.5} \mathrm{O}_{x}$. We, therefore, conclude that the compound formed in $\mathrm{Ga}$-added $\mathrm{Bi}_{2-x} \mathrm{Ga}_{x} \mathrm{Sr}_{2} \mathrm{Ca}_{2} \mathrm{Cu}_{3} \mathrm{O}_{y}$ samples is $\mathrm{GaSr}_{0.55} \mathrm{Ca}_{1.05} \mathrm{Cu}_{0.5} \mathrm{O}_{x}$.

On the other hand, any peaks related to superconducting phases of Ga-based system, however, are not observed even in Ga-rich samples. It is concluded that high pressure superconducting phases in the Ga-based system are not formed in the preparation process of melt-quenching or glass-ceramics at atmospheric pressure, in which sometimes metastable or unequilibrium phase is formed in glass-ceramic processing.

\section{Conclusions}

The effect of Ga-addition on the glass forming ability and superconducting properties of $\mathrm{Bi}_{2-x} \mathrm{Ga}_{x} \mathrm{Sr}_{2} \mathrm{Ca}_{2} \mathrm{Cu}_{3} \mathrm{O}_{y}$ samples was studied using a glass-ceramic processing. The possibility of the formation of high pressure Ga-based superconducting phases at atmospheric pressure was also checked in this unique processing. The addition of $\mathrm{GaO}_{3 / 2}$ up to $x=0.5$ improved slightly the glass-forming ability of the samples. However, any presence of gallium was found to deteriorate the superconducting properties of the Bi-based superconductors. The Ga-based compound formed in Ga-rich samples was identified to be $\mathrm{GaSr}_{0.55} \mathrm{Ca}_{1.05} \mathrm{Cu}_{0.5} \mathrm{O}_{x}$. Any of high pressure superconducting phases of Ga-based system was not formed even in Ga-rich samples.

\section{References}

1) H. Maeda, Y. Tanaka, M. Fukutomi and T. Asano, Jpn. J. Appl. Phys., 27, L209-10 (1988).

2) T. Komatsu, T. Ohki, C. Hirose and K. Matusita, J. NonCryst. Solids, 113, 274-81 (1989).

3) H. Sato, W. Zhu and T. Ishiguro, J. Solid State Chem., 75, 207-11 (1988).

4) T. Komatsu, Mater. Sci. Forum, 97, 130-32 (1993).

5) E. T. Muromachi and M. Isobe, Jpn. J. Appl. Phys., 33, L1399-402 (1994).

6) M. Murugesan, P. Selvam and M. Sharon, Appl. Phys. Lett., 67, 2711-13 (1995).

7) S. Hahakura, Physica C, 233, 1-7 (1994)

8) W. H. Dumbaugh, Phys. Chem. Glasses, 27, 119-23 (1986).

9) G. Whichard and D. E. Day, J. Non-Cryst. Solids, 66, 477-87 (1984).

10) K. Oda, H. Kitaguchi, J. Takada, A. Osaka, Y. Miura, Y. Ikeda, M. Takano, Y. Bando, Y. Tomii, Y. Oka, N. Yamamoto, Y. Takeda and H. Mazaki, Jpn. J. Appl. Phys., 35, 959-64 (1988).

11) T. Komatsu, T. Ohki, K. Matusita and T. Yamashita, Seramikkusu Ronbunshi, 97, 251-55 (1989).

12) T. Komatsu, M. Nakakura, R. Sato, J. Khaled and K. Matusita, J. Non-Cryst. Solids, 195, 102-12 (1996).

13) L. Demesso, I. Matsubara, T. Ogura, R. Funahashi, H. Yamashita and A. Tampieri, J. Mater. Res., 9, 2501-09 (1994).

14) N. Kannan, C. Bansal and G. Rajaram, Solid State Commun., 81, 109-13 (1992).

15) J. Khaled, T. Komatsu and R. Sato, submitted to J. Ceram. Soc. Japan. 